\title{
ADAPTIVE REUSE ON BIOSKOP DIAN AS A CULTURAL HERITAGE BUILDING GROUP A IN BANDUNG CITY
}

\author{
${ }^{1}$ Vanessa Adinda Rahmadya. ${ }^{2}$ Dr. Ir. Harastoeti Dibyo Hartono, MSA \\ ${ }^{1}$ Student in the Bachelor's (S-1) Study Program in Architecture \\ at Parahyangan Catholic University \\ 2 Senior lecturer in the Bachelor's (S-1) Study Program in Architecture \\ at Parahyangan Catholic University
}

\begin{abstract}
Dian Cinema is an entertainment building in the form of a cinema that was built in 1930 under the name Radio City at that time. Located on Jalan Dalem Kaum no. 58, Bandung, Dian Cinema is the only cinema building left in the Alun - alun area and it is categorized as Group A Cultural Heritage Building in Bandung. In the beginning, Dian Cinema had experienced its heyday by showing a variety of foreign and local films, until it was eventually replaced with a new, more modern cinema concept that made Dian Cinema visitors diminished and eventually closed.

The transition of functions in this building continues as a billiard sports venue, a place to sell clothes, rental offices, football sports venues, until now, Dian cinema is run into a vacuum of function. This makes the condition of the building become untreated and unmaintained well. In fact, the use of buildings in the right way can save these buildings and have a positive impact on the surrounding environment. Therefore, the proposed of a new function commonly referred to as adaptive reuse is carried out as one of the conservation act of cultural heritage buildings to maintain its history and existence.

The study uses descriptive methods with qualitative analysis and evaluation, by describing the existing condition of the building. After that, it was conducted on the needs of the area in accordance with Bandung City regulations, conservation theory, analysis of the area and buildings, as well as examples of the successful application of adaptive reuse in Indonesia.

The results of this study resulted in a new function, the Art Studio and the Performing Gallery which was considered applicable to the Dian Cinema building. The function is chosen based on a series of analysis results such as location, historical value, building characteristics, spatial requirements, to the potential and constraints of the building and area. The existence of new functions in the building is expected to be able to evoke social activities and old historical memories that are starting to fade, increase public knowledge, become an entertainment building and educational tourist destinations, and can participate in maintaining, protecting, and utilizing the existence of Group A Cultural Heritage Buildings in Bandung.
\end{abstract}

Key Words: Adaptive Reuse, Cultural Heritage Building, Bioskop Dian

\section{ADAPTIVE REUSE PADA BIOSKOP DIAN SEBAGAI BANGUNAN CAGAR BUDAYA GOLONGAN A DI KOTA BANDUNG}

\author{
${ }^{1}$ Vanessa Adinda Rahmadya. ${ }^{2}$ Dr. Ir. Harastoeti Dibyo Hartono, MSA \\ ${ }^{1}$ Mahasiswa S1 Program Studi Arsitektur Universitas Katolik Parahyangan. \\ 2 Dosen Pembimbing S1 Program Studi Arsitektur Universitas Katolik Parahyangan.
}

\begin{abstract}
Abstrak- Bioskop Dian merupakan bangunan hiburan berupa bioskop yang dibangun pada tahun 1930 dengan nama Radio City pada zaman itu. Berlokasi di Jalan Dalem Kaum no. 58, Bandung, Bioskop Dian ini menjadi satu-satunya bangunan bioskop yang tersisa di kawasan Alun - alun dan dijadikan sebagai Bangunan Cagar Budaya Golongan A di Kota Bandung. Pada mulanya, Bioskop Dian ini sempat mengalami masa kejayaannya dengan menayangkan berbagai film luar negeri maupun lokal, hingga pada akhirnya tergantikan dengan konsep bioskop baru yang lebih modern sehingga membuat pengunjung Bioskop Dian ini berkurang dan pada akhirnya tutup.
\end{abstract}

\footnotetext{
${ }^{1}$ Corresponding Author: 4216079@ student.unpar.ac.id
} 
Peralihan fungsi pun terus dilakukan seperti dijadikan tempat olahraga bilyar, tempat berjualan pakaian, kantor sewa, tempat olahraga futsal, hingga saat ini Bioskop Dian mengalami kekosongan fungsi. Kekosongan ini membuat kondisi bangunan menjadi tidak terawat dan terpelihara. Padahal, pemanfaatan bangunan dengan cara yang tepat dapat menyelamatkan bangunan ini dan memberi dampak positif terhadap lingkungan sekitarnya. Maka dari itu, dilakukan usulan penerapan fungsi baru yang biasa disebut dengan istilah adaptive reuse sebagai salah satu tindakan konservasi terhadap bangunan cagar budaya untuk mempertahankan sejarah dan eksistensinya. Penelitian ini menggunakan metode deskriptif dengan analisa dan evaluasi kualitatif, yaitu dengan menggambarkan kondisi eksisting bangunan. Setelah itu dilakukan kajian terhadap kebutuhan kawasan sesuai dengan regulasi Kota Bandung, teori konservasi, analisis kawasan dan bangunan, serta contoh keberhasilan penerapan adaptive reuse di Indonesia.

Hasil dari penelitian ini menghasilkan sebuah fungsi baru yaitu Sanggar Seni dan Galeri Pertunjukkan yang dinilai dapat diaplikasikan pada bangunan Bioskop Dian. Fungsi tersebut dipilih berdasarkan serangkaian hasil analisis seperti lokasi, nilai sejarah, karakteristik bangunan, kebutuhan ruang, hingga potensi dan kendala pada bangunan dan kawasan. Adanya fungsi baru pada bangunan tersebut diharapkan dapat membangkitkan aktivitas sosial serta memori sejarah lama yang mulai pudar, meningkatkan wawasan masyarakat, menjadi destinasi wisata hiburan serta edukasi, dan dapat turut serta memelihara, melindungi, dan memanfaatkan eksistensi Bangunan Cagar Budaya Golongan A di Kota Bandung.

Kata Kunci: Adaptive Reuse, Bangunan Cagar Budaya, Bioskop Dian

\section{PENDAHULUAN}

Kota Bandung menjadi salah satu kota yang mempunyai nilai sejarah tinggi di Indonesia. Banyak peristiwa penting terjadi di Kota Bandung yang meninggalkan jejak sejarahnya, salah satunya ialah kawasan Alun-alun. Terciptanya Alun-Alun sebagai pusat kota mempengaruhi fungsi bangunan di kawasan sekitarnya seperti adanya restoran, kantor pos, bangunan hiburan, dan lainnya. Salah satu yang menjadi primadona saat itu ialah bangunan hiburan berupa bioskop. Setidaknya tercatat terdapat lima gedung bioskop di kawasan AlunAlun, diantaranya ialah bioskop bernama Radio City yang kemudian berubah nama menjadi Bioskop Dian.

Radio City atau Bioskop Dian yang berlokasi di Jalan Dalem Kaum No. 58, Bandung ini dibangun pada tahun 1930 yang dikelola oleh J. F. W. de Kort dan Thio Tjoan Tek. Sayangnya pada tahun 1990an, Bioskop Dian ini mulai sepi pengunjung akibat tergantikan oleh konsep bioskop baru yang lebih modern di pusat-pusat perbelanjaan Kota Bandung sehingga Bioskop Dian pun pada akhirnya terpaksa untuk berhenti beroperasi. Saat ini Bioskop Dian mengalami kekosongan fungsi sehingga bangunan tersebut menjadi tidak terawat dan menjadi sarana berjualan pedagang kaki lima bahkan dijadikan sarana tidur untuk gelandangan di malam hari.

Padahal, Bioskop Dian ini merupakan salah satu bangunan bioskop yang masih berdiri di kawasan Alun-Alun Kota Bandung. Bioskop Dian dikategorikan sebagai Bangunan Cagar Budaya Golongan A yang terlampir pada Lampiran Peraturan Daerah Kota Bandung Nomor 7 Tahun 2018 Tentang Pengelolaan Cagar Budaya karena memiliki kekayaan budaya bangsa yang penting bagi pemahaman dan pengembangan sejarah, kebudayaan, serta ilmu pengetahuan. Sehingga, keberadaan Bioskop Dian sebagai bangunan cagar budaya perlu dilindungi dan dilestarikan.

Fenomena terbengkalainya Bioskop Dian akibat bangunan tersebut tidak mewadahi sebuah fungsi menjadi rumusan masalah yang diteliti dalam penelitian ini, karena bangunan tersebut seharusnya dilindungi dan dimanfaatkan dengan baik sebagaimana yang sudah tercantum dalam undang-undang. Hal itu memunculkan pertanyaan penelitian "Apa fungsi baru yang sesuai untuk diaplikasikan pada Bioskop Dian sebagai Bangunan Cagar Budaya Golongan A di Kota Bandung?” 
Tujuan dari penelitian ini ialah mencari fungsi baru yang sesuai untuk diaplikasikan pada Bioskop Dian sebagai bangunan cagar budaya golongan, mempelajari teknik konservasi adaptive reuse pada bangunan cagar budaya dan mengidentifikasi kondisi fisik bangunan Bioskop Dian. Penelitian ini diharapkan dapat memberikan wawasan baru pada pembaca mengenai upaya adaptive reuse sebagai salah satu bentuk konservasi. Diharapkan pula penelitian ini dapat dijadikan sebagai bahan pertimbangan bagi pihak pengelola sebagai usulan fungsi baru yang sesuai untuk diaplikasikan pada Bioskop Dian sebagai bentuk upaya perlindungan, pemanfaatan, dan pengembangan pada bangunan cagar budaya di Kota Bandung.

\section{KAJIAN TEORI}

\subsection{TEORI CAGAR BUDAYA}

Cagar Budaya menurut International Council Monuments of Site (ICOMOS, 2002) adalah ekspresi cara hidup yang dikembangkan oleh suatu komunitas dan diwariskan dari generasi ke generasi, termasuk adat istiadat, praktik, tempat, benda, ekspresi dan nilai artistik. Cagar Budaya sering dinyatakan sebagai warisan cagar budaya yang tidak berwujud (intangible) seperti nyanyian dan tradisi, serta bersifat nyata/ berwujud (tangible) seperti bangunan, artefak, dan benda. ${ }^{2}$

Sedangkan, menurut Undang - Undang Republik Indonesia No. 11 Tahun 2010 tentang Cagar Budaya "Cagar Budaya adalah warisan budaya bersifat kebendaan berupa Benda Cagar Budaya, Bangunan Cagar Budaya, Struktur Cagar Budaya, Situs Cagar Budaya, dan Kawasan Cagar Budaya di darat dan/ atau di air yang perlu dilestarikan keberadaannya karena memiliki nilai penting bagi sejarah, ilmu pengetahuan, pendidikan, agama, dan/ atau kebudayaan melalui proses penetapan."

Bangunan Cagar Budaya merupakan adalah susunan binaan yang terbuat dari benda alam atau benda buatan manusia untuk memenuhi kebutuhan ruang berdinding dan/atau tidak berdinding, dan beratap. ${ }^{3}$

Menurut Perda Kota Bandung No. 7 Tahun 2018, terdapat kriteria untuk penggolongan Bangunan Cagar Budaya Daerah Kota, berikut kriteria beserta penjelasannya:

\section{a. Nilai Sejarah}

Berkaitan dengan peristiwa atau sejarah politik (perjuangan), sejarah dan ilmu pengetahuan, sejarah budaya termasuk di dalamnya sejarah kawasan maupun bangunan,tokoh penting baik pada tingkat lokal (Bandung atau Jawa Barat), nasional (Indonesia) maupun internasional.

\section{b. Nilai Arsitektur}

Berkaitan dengan wajah bangunan (komposisi elemenelemen dalam tatanan lingkungan) dan gaya tertentu (wakil dari periode gaya tertentu) serta keteknikan. Termasuk di dalam nilai arsitektur adalah fasad, layout dan bentuk bangunan, warna serta ornamen yang dimiliki oleh bangunan. Juga berkaitan dengan perkembangan ilmu pengetahuan atau menunjang ilmu pengetahuan, misalnya, bangunan yang dibangun dengan teknologi tertentu atau teknologi baru (termasuk di dalamnya penggunaan konstruksi dan material khusus). Bangunan yang merupakan perkembangan tipologi tertentu.

\section{c. Nilai Ilmu Pengetahuan}

\footnotetext{
${ }^{2}$ International Cultural Tourism Charter: Managing Tourism at Places of Heritage Significance, ICOMOS, 1999, hlm. 1.

${ }^{3}$ Indonesia, Peraturan Daerah Kota Bandung Nomor 7 Tahun 2018 Tentang Pengelolaan Cagar Budaya, BAB I, Ps 1.
} 
Nilai ilmu pengetahuan, yaitu bangunan-bangunan yang memiliki peran dalam pengembangan ilmu pengetahuan, misalnya ITB, UPI, dan Museum Geologi.

\section{d. Nilai Sosial Budaya}

Nilai sosial budaya (collective memory), berkaitan dengan hubungan antara masyarakat dengan locusnya, yaitu kawasan maupun bangunan yang sangat lekat dengan hati masyarakatnya serta kawasan/bangunan yang memiliki peran besar dalam meningkatkan kehidupan sosial masyarakat.

\section{e. Umur}

Berkaitan dengan umur objek konservasi. Umur yang ditetapkan adalah sekurang - kurangnya 50 (lima puluh) tahun. Semakin tua bangunan, semakin tinggi nilai ke-'tuaannya'.

Berdasarkan kriteria yang sudah disebutkan sebelumnya, bangunan cagar budaya dibagi dalam tiga (3) golongan, yaitu:

1. Bangunan Cagar Budaya golongan A (Utama) adalah bangunan yang berusia paling sedikit 50 tahun ditambah paling sedikit 3 (tiga) kriteria lainnya.

2. Bangunan Cagar Budaya golongan B (Madya) adalah bangunan yang berusia paling sedikit 50 tahun ditambah paling sedikit 2 (dua) kriteria lainnya.

3. Bangunan Cagar Budaya golongan $\mathrm{C}$ (Pratama) adalah bangunan yang berusia paling sedikit 50 tahun ditambah paling sedikit 1 (satu) kriteria lainnya.

\subsection{TEORI KONSERVASI}

Konservasi adalah tindakan yang diambil untuk mencegah kerusakan. Tindakan tersebut melingkupi semua upaya untuk memperpanjang warisan cagar budaya. ${ }^{4}$ Konservasi itu sendiri secara harfiah berasal dari kata bahasa inggris conservation yang artinya pelestarian atau perlindungan.

Pelestarian cagar budaya ditekankan pada upaya Pelindungan, Pengembangan, dan Pemanfaatan yang dapat dilakukan dengan berbagai tindakan. Diantaranya ialah: ${ }^{5}$

\section{a. Pelindungan}

Pelindungan merupakan upaya mencegah dan menanggulangi dari kerusakan, kehancuran, atau kemusnahan dengan cara Penyelamatan, Pengamanan, Zonasi, Pemeliharaan, dan Pemugaran Cagar Budaya.

\section{b. Pengembangan}

Pengembangan adalah peningkatan potensi nilai, informasi, dan promosi Cagar Budaya serta pemanfaatannya melalui Penelitian, Revitalisasi, dan Adaptasi secara berkelanjutan serta tidak bertentangan dengan tujuan Pelestarian.

\section{c. Pemanfaatan}

Pemanfaatan adalah pendayagunaan Cagar Budaya untuk kepentingan sebesarbesarnya kesejahteraan rakyat dengan tetap mempertahankan kelestariannya.

Pemerintah, Pemerintah Daerah, dan setiap orang dapat memanfaatkan Cagar Budaya untuk kepentingan agama, sosial, pendidikan, ilmu pengetahuan, teknologi, kebudayaan, dan pariwisata.

Upaya konservasi dilaksanakan sesuai dengan klasifikasi golongannya, yaitu: ${ }^{6}$ hlm. 3 .

\footnotetext{
${ }^{4}$ Bernard M. Feilden, Conservation of Historic Building, (Oxford: Butterworth-Heinemann Ltd, 1982),
}

${ }^{5}$ Indonesia, Undang-Undang Nomor 10 Tahun 2011 Tentang Cagar Budaya, BAB VII.

${ }^{6}$ Indonesia, Peraturan Daerah Kota Bandung Nomor 7 Tahun 2018 Tentang Pengelolaan Cagar Budaya, BAB IX, Ps. 44-46. 
a. Pelaksanaan pelestarian Bangunan dan Struktur Cagar Budaya golongan A dilaksanakan sebagai berikut:

1) Bangunan dan/atau struktur dilarang dibongkar dan/atau diubah

2) Dalam hal kondisi fisik bangunan dan/atau struktur buruk, roboh, terbakar atau tidak layak tegak, harus dibangun kembali sama seperti semula sesuai dengan aslinya

3) Pemeliharaan dan perawatan bangunan dan/atau struktur harus menggunakan bahan yang sama/sejenis atau memiliki karakter yang sama, dengan mempertahankan detil ornamen bangunan yang telah ada

4) Dalam upaya revitalisasi dimungknkan adanya penyesuaian fungsi sesuai rencana kota yang berlaku tanpa mengubah bentuk bangunan dan struktur aslinya

5) Dalam situs Cagar Budaya dimungkinkan adanya bangunan tambahan selain bangunan utama

6) Penambahan bangunan hanya dapat dilakukan di belakang dan/atau di samping bangunan atau struktur Cagar Budaya dengan jarak tertentu dari bangunan utama dan harus sesuai dengan karakter arsitektur Bangunan Cagar Budaya dalam keserasian lingkungan.

b. Pelaksanaan pelestarian Bangunan Cagar Budaya atau Struktur Cagar Budaya golongan B, dilaksanakan sebagai berikut:

1) Bangunan dan/atau struktur dilarang dibongkar secara sengaja, dan apabila kondisi fisik bangunan buruk, roboh, terbakar atau tidak layak tegak harus dibangun kembali sama seperti semula sesuai dengan aslinya

2) Perubahan bangunan dan/atau struktur harus dilakukan tanpa mengubah karakter bangunan dan/atau struktur serta dengan mempertahankan detil dan ornament bangunan yang mewakili karakter Bangunan Cagar Budaya dan Struktur Cagar Budaya

3) Dalam upaya rehabilitasi dan revitalisasi dimungkinkan adanya perubahan fungsi dan tata ruang dalam asal tidak mengubah karakter struktur utama bangunan.

4) Dalam Situs Cagar Budaya dimungkinkan adanya bangunan tambahan yang mengacu pada karakter arsitektur Bangunan Cagar Budaya dalam keserasian lingkungan.

c. Pelaksanaan pelestarian Bangunan Cagar Budaya golongan C dilaksanakan dengan ketentuan sebagai berikut:

1) Perubahan bangunan dapat dilakukan dengan tetap mempertahankan karakter utama bangunan.

2) Detail ornamen dan bahan bangunan disesuaikan dengan arsitektur bangunan di sekitarnya dalam keserasian lingkungan.

3) Dalam Situs Cagar Budaya dimungkinkan adanya bangunan tambahan yang sesuai dengan karakter lingkungan

4) Fungsi bangunan dapat diubah sesuai dengan rencana tata ruang

Tujuan konservasi yaitu: ${ }^{7}$

a. Melestarikan warisan budaya bangsa dan warisan umat manusia

\footnotetext{
${ }^{7}$ Indonesia, Undang-Undang Nomor 11 Tahun 2010 Tentang Cagar Budaya, Ps. 2.
} 
b. Meningkatkan harkat dan martabat bangsa melalui Cagar Budaya

c. Memperkuat kepribadian bangsa

d. Meningkatkan kesejahteraan rakyat

\subsection{TEORI ADAPTIVE REUSE}

e. Mempromosikan warisan budaya bangsa kepada masyarakat internasional

Adaptasi itu sendiri menurut The Burra Charter (1999) merupakan memodifikasi sebuah tempat agar sesuai dengan penggunaan yang ada atau penggunaan yang diusulkan. Adaptasi dapat melibatkan perbaikan baru, atau fungsi baru, atau perubahan untuk menjaga tempat tersebut. ${ }^{8}$

Terdapat prinsip-prinsip yang diterapkan atau diutamakan pada saat melakukan upaya adaptive reuse. Hal ini dilakukan agar tidak merusak bangunan cagar budaya dan nilai-nilai yang terkandung didalamnya. Beberapa prinsip yang diterapkan antara lain: ${ }^{9}$

a. Memory and Place (Memori dan Tempat)

Sebuah bangunan cagar budaya tidak hanya sebagai bangunan, namun sebagai penyimpan sejarah atau memori. Bangunan yang memiliki sejarah atau memori dipengaruhi oleh lingkungan sekitar atau suatu peristiwa tertentu. Sehingga, dalam menentukan fungsi perlu dipertimbangkan potensi perubahan fisik bangunan agar makna sejarah pada bangunan tersebut tidak memudar.

b. Planning Controls / Pengawasan Perencanaan

Dalam menentukan fungsi yang sesuai pada bangunan cagar budaya, terdapat regulasi yang harus dipatuhi dalam mengatur kawasan tersebut yang sudah ditetapkan sebelumnya oleh pemerintah setempat.

c. Environment Sustainability/ Kelestarian Lingkungan

Lingkungan menjadi salah satu hal yang patut diperhatikan. Dampak yang akan ditimbulkan dari bangunan tersebut terhadap lingkungannya perlu menjadi pertimbangan dalam perencanaan dan diusahakan untuk tidak merusak lingkungan sekitarnya.

d. Social Sustainability / Keberlanjutan Sosial

Fungsi baru pada bangunan cagar budaya memberi pengaruh pada faktor sosial. Fungsi yang ditempatkan diharapkan dapat memenuhi kebutuhan sosial untuk masyarakat sekitar dan diharapkan bangunan tersebut menjadi wadah bagi aktivitas sosial, dengan adanya aktivitas tersebut dapat membantu menghidupkan kembali bangunan cagar budaya.

e. Efficiency / Efisiensi

Idealnya, fungsi baru di dalam bangunan tersebut memberikan efisiensi pada bangunan cagar budaya, baik dari segi ekonomi, sosial, dan kebutuhan ruang sehingga bangunan cagar budaya dapat bertahan lama dan terus berlanjut.

f. Authenticity / Keaslian

Sebagai bangunan cagar budaya yang dilindungi, sangat penting untuk menjaga keaslian bangunan agar nilai yang terkandung di dalamnya tidak hilang dan terus terjaga. Manfaat sekaligus keuntungan yang didapat dari upaya adaptive reuse ini adalah: ${ }^{10}$
a. Penghematan biaya dalam bahan bangunan
b. Penghematan biaya dalam pembongkaran/ penghancuran
c. Penghematan waktu
d. Kentungan pajak

\footnotetext{
${ }^{8}$ The Burra Charter : The Australia ICOMOS Charter for Places of Cultural Significance, ICOMOS, 1999, hlm. 2 .

${ }^{9}$ ODASA Design Guidance Note: Adaptive Re-Use, Office for Design+Architecture SA (ODASA), 2014, hlm. 3 .

${ }^{10}$ Gene Bunnel, "Built to Last: A Handbook on Recycling Old Buildings", diakses dari https://worddisk.com/wiki/Adaptive_reuse/, pada tanggal 16 April 2020 pukul 19.27.
} 
e. Menghemat energi

Salah satu contoh penerapan adaptive reuse di Indonesia yang dinyatakan berhasil adalah EksPabrik Gula Tjolomadoe/ De Tjolomadoe.

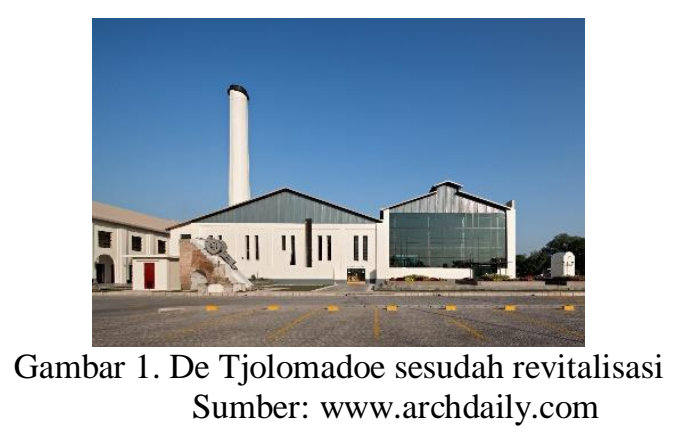

Adanya latar belakang sejarah yang kuat menjadikan bangunan Pabrik Gula (PG) Colomadu di Karanganyar, Jawa Tengah sebagai salah satu warisan cagar budaya. Pabrik ini dibangun pada tahun 1861, pabrik tersebut merupakan pabrik gula pertama di Indonesia. Setelah sekitar dua dekade berhenti beroperasi, kondisi bangunan ini terbengkalai dan mengalami degradasi karena operasional pabrik tidak difungsikan. Hal ini mendorong Kementerian Badan Usaha Milik Negara (BUMN) untuk merevitalisasi bangunan tersebut hingga dapat difungsikan kembali dengan melakukan rebranding menjadi De Tjolomadoe.

Berdasarkan hasil kajian, De Tjolomadoe difungsikan sebagai sebuah destinasi wisata heritage, pusat kebudayaan, dan area komersial yang mengikuti kaidah cagar budaya. Setelah dilakukan revitalisasi dan rebranding, kini bangunan tersebut menjadi sebuah destinasi wisata heritage sebagai pusat kebudayaan dan area komersial. Fasilitas yang terdapat pada De Tjolomadoe ini diantaranya ialah museum, area komersial, cafe, serta fasilitas Meetings, Incentives, Convention and Exhibitions (MICE). De Tjolomadoe menjadi salah satu destinasi wisata baru di Jawa Tengah yang mampu meningkatkan produktivitas ekonomi daerah Karanganyar, sekaligus mengembangkan aspek seni, heritage, dan pariwisata di kawasan tersebut. Dikutip dalam Koran Sindo, Dalam satu bulan, De Tjolomadoe kini memiliki pengunjung rata-rata mencapai $70.000-90.000$ orang. Saat masa liburan, jumlahnya meningkat banyak hingga mencapai 150.000-200.000 orang perbulan. Banyaknya pengunjung yang hadir menandakan kesuksesan sebuah revitalisasi dalam menghidupkan kembali kawasan maupun bangunan yang dahulu mati.

\section{METODE PENELITIAN}

Bentuk metodologi yang dilakukan dalam studi ini yaitu metode penelitian deskriptif - kualitatif. Tujuan dari metode deskriptif adalah untuk membuat deskripsi, gambar, atau lukisan secara sistematis, faktual, dan akurat mengenai fakta, sifat serta hubungan antar fenomena yang diteliti. Sedangkan, tujuan dari penelitian kualitatif ialah mengumpulkan informasi yang dapat menjelaskan fenomenasecara mendalam dan menyeluruh dengan cara pengumpulan data objek yang akan diteliti. Bioskop Dian menjadi objek studi dalam penelitian. Lokasinya berada di Jalan Dalem Kaum No. 58, Kota Bandung, Jawa Barat, Indonesia.

Populasi dan sampel yang diambil berupa pengumpulan data bangunan, dokumentas bangunan, serta wawancara dengan perwakilan dari pihak pengelola. Tahap selanjutnya akan dianalisis dengan cara mengkaji data yang diperoleh dengan studi literatur seperti teori konservasi, teori adaptive reuse, dan upaya konservasi yang dilakukan sesuai dengan Undang- 
Undang RI no. 11 Tahun 2010 Tentang Cagar Budaya dan Peraturan Daerah Kota Bandung No. 7 Tahun 2018 Tentang Pengelolaan Cagar Budaya.

\section{ANALISIS}

\subsection{SEJARAH SINGKAT BANGUNAN BIOSKOP DIAN}

Bangunan ini didirikan pada tahun 1930 dengan nama Radio City Bioskop yang sekarang dikenal sebagai Bioskop Dian, merupakan satu-satunya gedung bioskop yang tersis di kawasan Alun-alun Bandung.

Pada tahun 1946, terjadi peristiwa Bandung Lautan Api yang mengakibatkan bangunan ini ikut dibumihanguskan oleh warga Bandung. Hingga akhirnya pada tahun 1955, gedung bioskop ini dibangun kembali seperti bentuk aslinya dan diberi nama baru, yaitu Bioskop Dian.

Saat itu, Bioskop ini kembali ramai diminati. Bioskop ini memutarkan berbagai film lokal hingga film luar negeri bahkan bioskop ini juga sempat memutarkan film-film India atau bollywood dan kembali menikamati masa kejayaannya selama bertahun-tahun.

Peminat akan bioskop ini semakin berkuang setelah adanya bioskop baru yang lebih modern. Tak mampu bersaing, Bioskop Dian ini berhenti beroperasi di tahun 1994. Setelah itu, bangunan tersebut sempat kosong dan mulai mengalami peralihan fungsi.

\subsection{DESKRIPSI DATA OBJEK STUDI \\ Data Umum}

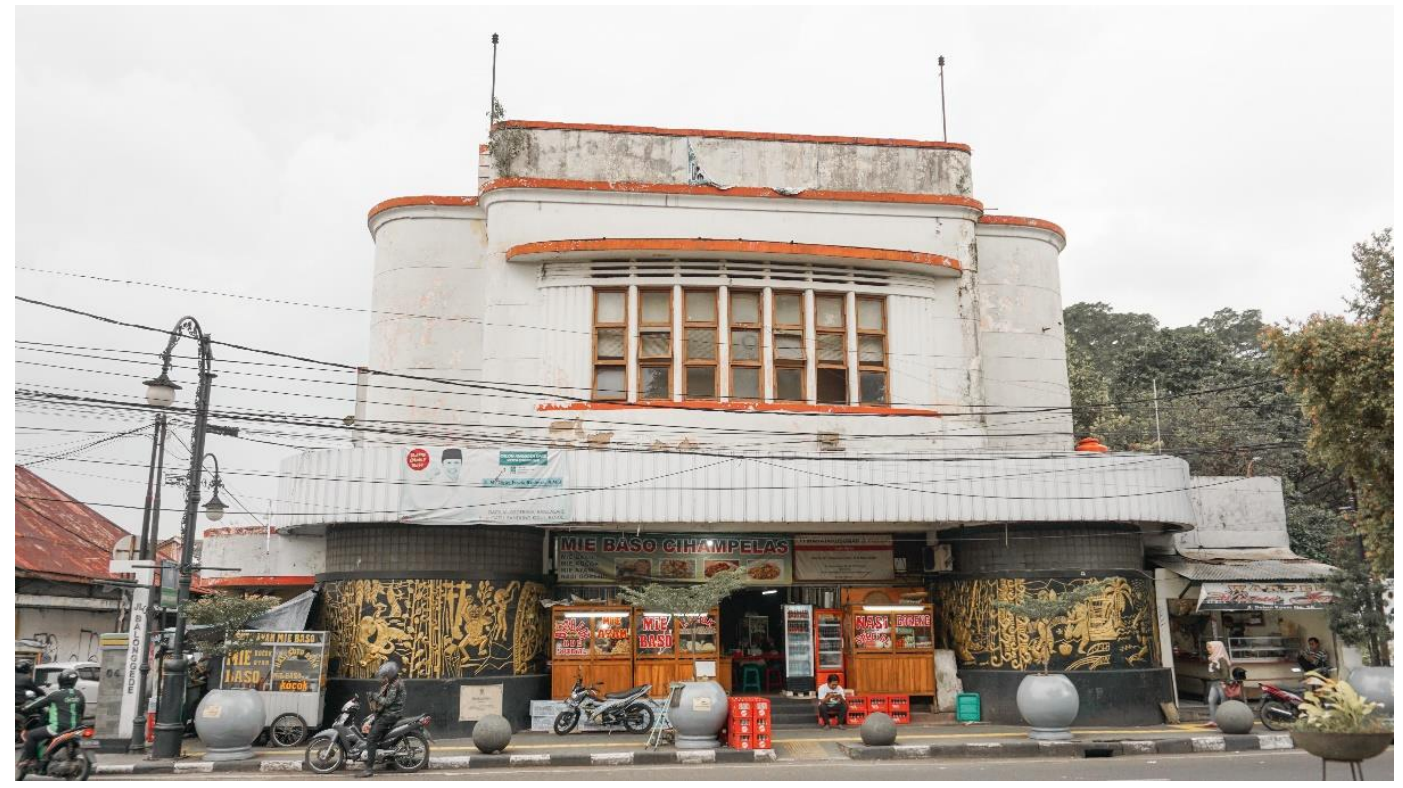

Gambar 2 Bioskop Dian Kota Bandung

$\begin{array}{ll}\text { Nama objek } & : \text { Bioskop Dian } \\ \text { Alamat } & : \text { Jalan Dalem Kaum No. 58, Bandung } \\ \text { Kecamatan } & : \text { Regol } \\ \text { Kelurahan } & : \text { Balonggede } \\ \text { Tahun Dibangun } & : 1930 \\ \text { Usia Bangunan } & : 90 \text { Tahun (hingga tahun 2020) } \\ \text { Luas Tapak } & : 1105 \mathrm{~m}^{2} \\ \text { Luas Bangunan } & : 1230 \mathrm{~m}^{2} \\ \text { Tinggi Bangunan } & : \pm 12 \text { meter }\end{array}$




\section{Batas Wilayah}

1) Batas wilayah utara

2) Batas wilayah barat

3) Batas wilayah timur

4) Batas wilayah selatan

\section{Denah Bangunan}

Denah Radio City (1930)

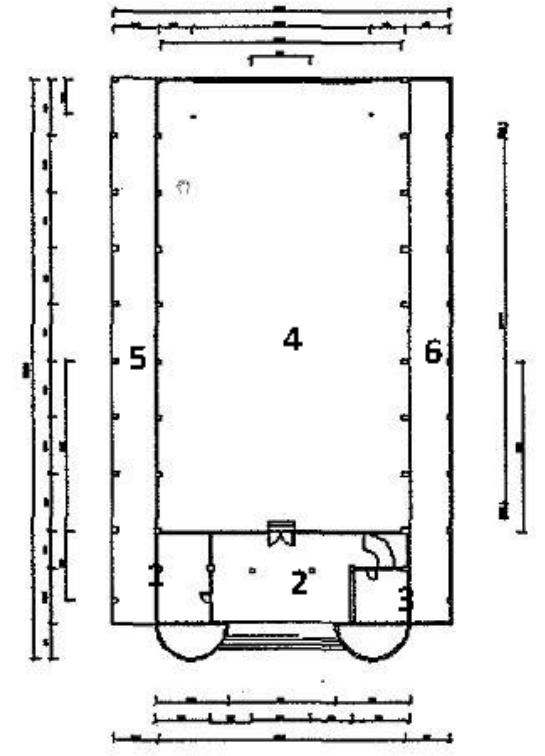

Denah lantai dasar

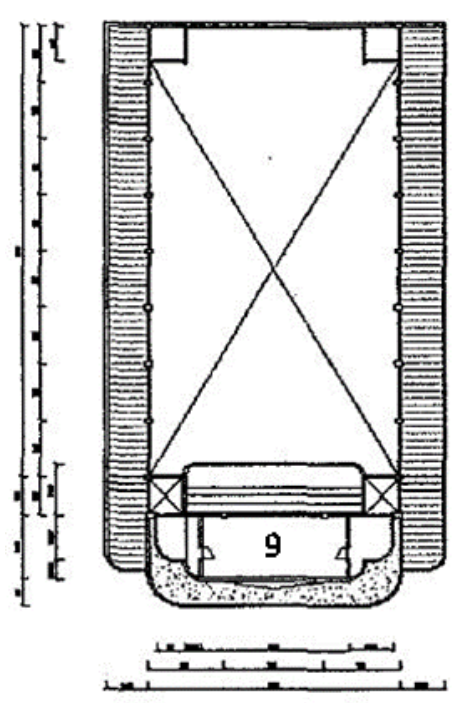

Denah lantai 2

Gambar 3 Denah Bioskop Dian pada tahun 1930

Sumber: Skripsi Upaya Konservasi pada Bangunan Ex-Bioskop Dian (2011)
: Jalan Dalem Kaum, Alun-alun, dan Lokasi Gedung Palaguna dan Ex- Bioskop Elita

: Pendopo Kota Bandung

: Jalan Balonggede dan Rumah Makan Padang

: Lahan kosong dan rumah penduduk

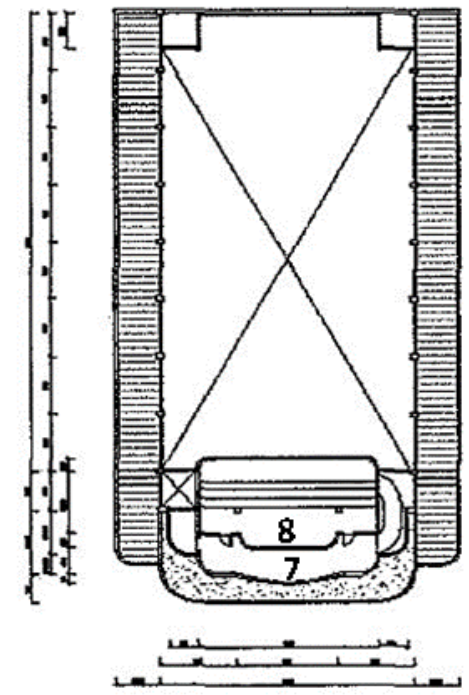

Denah lantai 1
Keterangan:

1. Ruang pengelola bioskop

2. Area pintu masuk

3. Loket penjualan tiket

4. Auditorium

5. Selasar

6. Jalur alternatif

7. Jalur sirkulasi

8. Tribun atas

9. Ruang pemutaran film 


\subsection{KONDISI BANGUNAN}
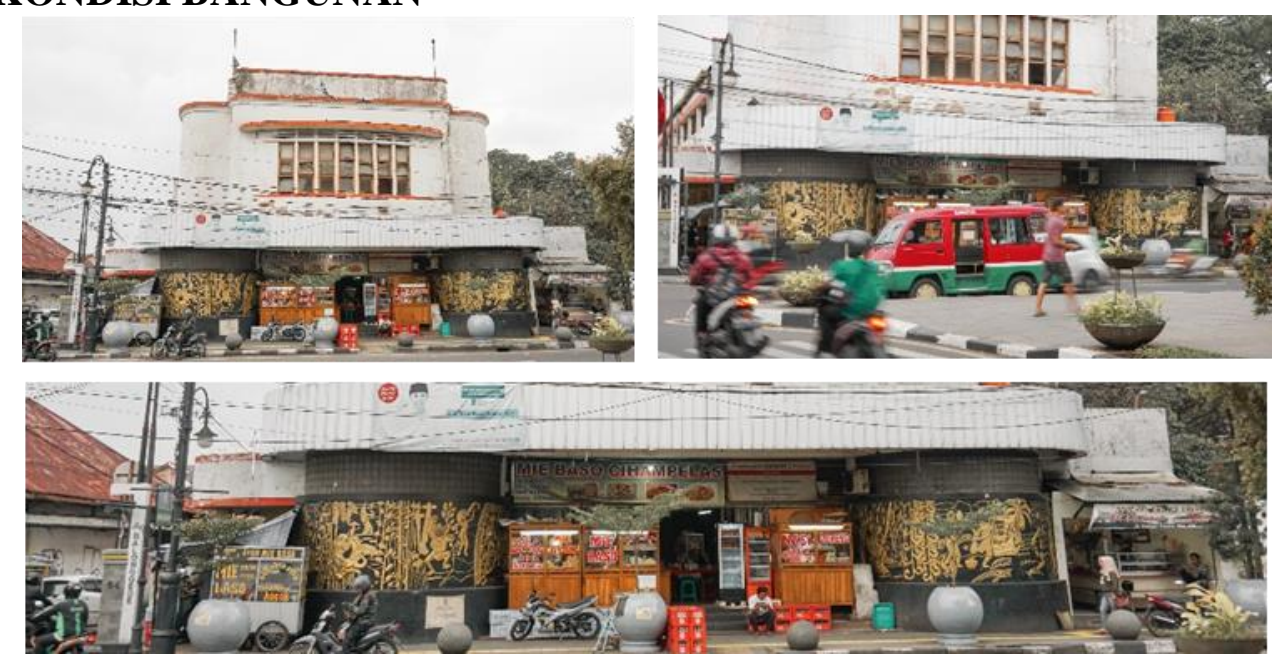

Gambar 4 Kondisi ruang luar Bioskop Dian

Kondisi ruang luar area depan pada Bioskop Dian terlihat kumuh. Fungsi yang seharusnya merupakan area pintu masuk menuju Bioskop Dian dialihfungsikan menjadi tempat berjualan para pedagang kaki lima.
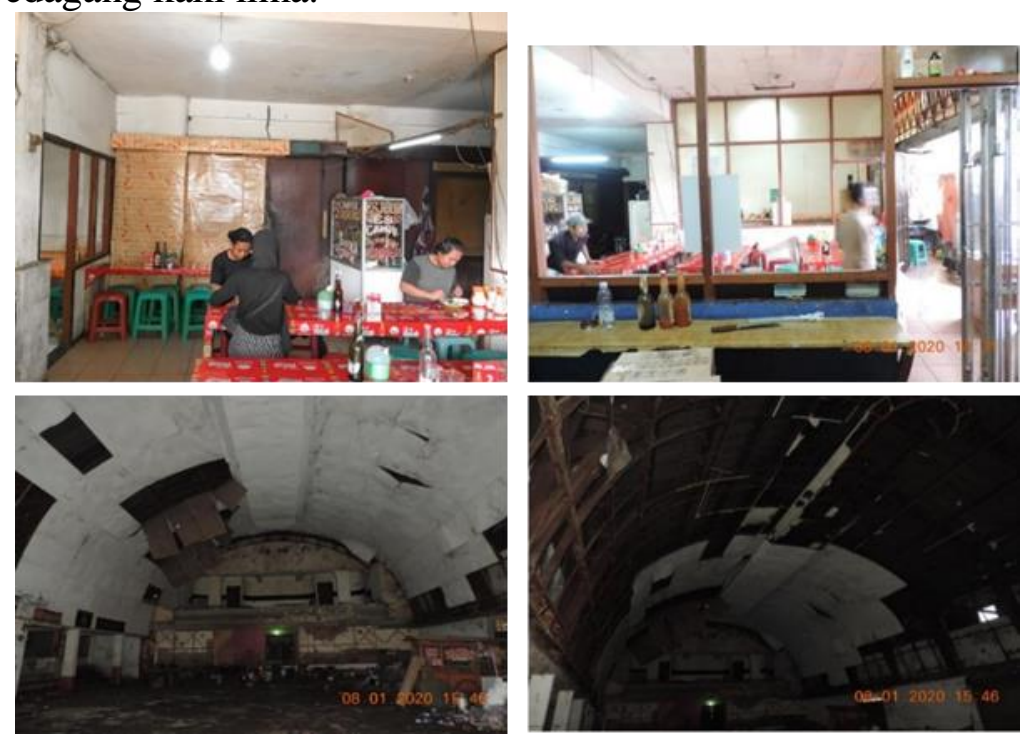

Gambar 5 Kondisi ruang dalam Bioskop Dian Sumber: Tim Ahli Cagar Budaya (2020)

Kondisi ruang dalam sangat kotor dan banyak sekali sampah, pada bagian auditorium banyak plafon yang sudah terlepas.

\section{4 ANALISIS PENERAPAN ADAPTIVE REUSE}

Langkah yang dilakukan sebelum menentukan fungsi baru pada bangunan terdiri dari beberapa tahap. Tahapan tersebut disusun berdasarkan faktor-faktor yang mempengaruhi sebuah perencanaan dalam perancangan arsitektur dimulai dari cakupan yang luas dan bersifat umum menuju cakupan yang lebih sempit dan bersifat lebih spesifik.

\subsection{REGULASI DAERAH}

Dalam Rencana Detail Tata Ruang Kota (RDTRK), lokasi bangunan termasuk ke dalam Subwilayah Kota (SWK) Karees, dimana SWK Karees merupakan pengembangan kawasan kreatif terpadu (karyapolis). 
Dalam RDTRK, Lokasi Bioskop Dian berada pada Zona K3a, yaitu Zona Perdagangan dan Jasa Linier.

Daftar fungsi yang diizinkan diatur dalam Tabel Ketentuan Kegiatan dan Penggunaan Lahan (ITBX) ini yang terlampir pada Peraturan Daerah Kota Bandung No. 10 Tahun 2015. Dalam Tabel ITBX tersebut dilampirkan daftar fungsi yang diizinkan untuk Zona K3, Zona Perdagangan dan Jasa Linier.

\subsection{ANALISIS KAWASAN}

Terdapat identitas pada sebuah kawasan tersebut. Identitas kawasan tersebut merupakan Alun-Alun Kota Bandung. Keberadaan Alun-Alun Bandung tidak terlepas dari sejarah pembentukan kota Bandung. Alun-alun kini menjadi salah satu destinasi wisata dari berbagai pengunjung dalam kota maupun luar kota.

Bangunan sekitar di kawasan tersebut didominasi oleh fungsi pertokoan, restoran, dan tempat hiburan. Sehingga, aktivitas yang terjadi di kawasan tersebut tidak jauh dari aktivitas jual-beli, mencari wisata kuliner, wisata sejarah, hingga tempat hiburan untuk bersenangsenang.

Potensi yang terdapat pada kawasan ini ialah letaknya yang berada di tengah kota sangat strategis sehingga menjadi sumber pusat keramaian. Selain itu, terdapat banyak bangunan bersejarah lainnya yang dapat menjadi potensi wisata. Kendala pada kawasan ini ialah kurangnya lahan parkir yang memadai di sekitar kawasan tersebut.

\subsection{PENCARIAN FUNGSI BARU}

\section{a. Potensi dan Kendala pada Bangunan}

Dalam mencari fungsi baru, perlu memperhatikan potensi dan kendala pada bangunan. Potensi yang terdapat pada bangunan Bioskop Dian ialah lokasinya yang berada di kawasan pusat kota, berada dekat dengan Taman Alun-alun Bandung dan Masjid Raya Bandung yang menjadi salah satu destinasi terkenal. Ramainya pengunjung pada kawasan itu membuat keuntungan pada bangunan yang termasuk dalam Zona Perdagangan dan Jasa Linier.

Selain itu, Bioskop Dian yang sudah ada sejak tahun 1930 ini memiliki nilai sejarah dan nilai arsitektur dengan gayanya yang khas sehingga menjadi keunikan tersendiri dari bangunan ini untuk mengangkat derajatnya sebagai Bangunan Cagar Budaya.

Kendala yang dimiliki pada bangunan yaitu adanya limitasi dalam melakukan upaya pelestarian pada sebuah Bangunan Cagar Budaya Golongan A.

\section{b. Karakteristik Ruang pada Bioskop Dian}

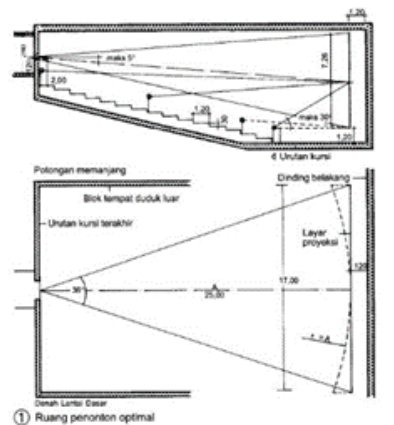

Gambar 6 Karakteristik bangunan bioskop

Sumber: Neufert Architect's Data (2002)

Bioskop Dian merupakan bangunan yang dahulu memang sengaja dibuat dan difungsikan sebagai sarana untuk menyaksikan pemutaran film yang biasa disebut sebagai bioskop. Bioskop menjadi salah satu bangunan hiburan yang dapat diminati oleh semua kalangan pengunjung. 
Bioskop memiliki tipologi yang sama dengan bangunan teater, sebab memiliki karakteristik yang tidak jauh berbeda. Terdapat auditorium sebagai area tempat duduk untuk penonton dan layar film dengan memperhatikan derajat kenyamanan visual.
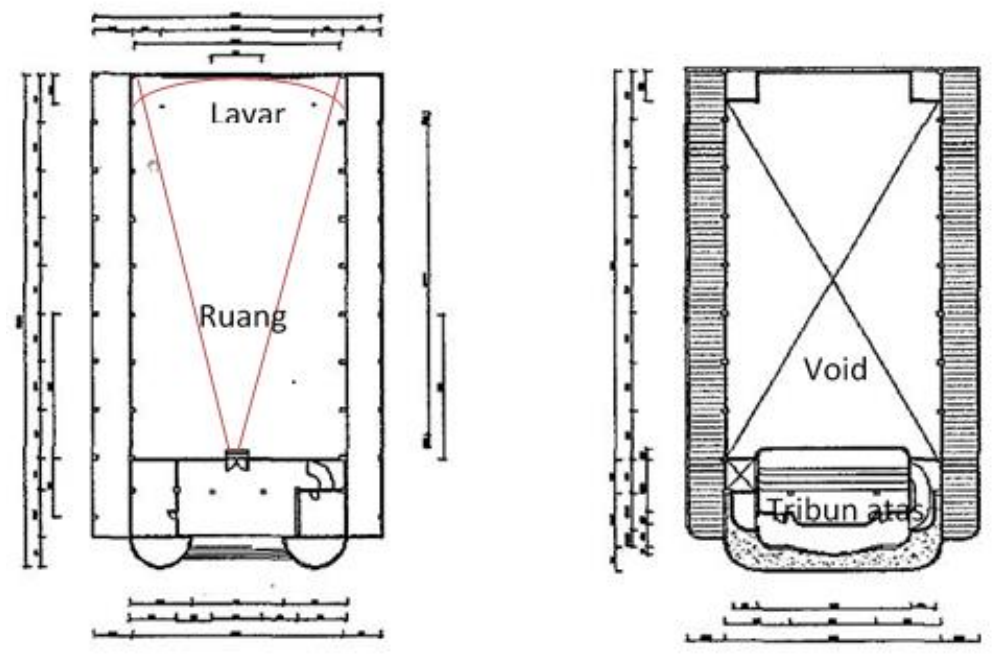

Gambar 7 Karakteristik Ruang Bioskop Dian

Sumber: Skripsi Upaya Konservasi pada Bangunan Ex-Bioskop Dian (2011)

Auditorium dengan luas 18 x 32 meter persegi pada Bioskop Dian menjadi karakter ruang yang kuat pada bangunan ini. Fungsi baru yang akan diaplikasikan harus mempertimbangkan auditorium ini sebagai ruang untuk menunjang kegiatan utama pada fungsi. Oleh karena itu, perlu adanya pertimbangan tipologi bangunan untuk menentukan fungsi baru agar fungsi tersebut sesuai dengan karakteristik ruang Bioskop Dian. Sehingga, pemanfaatan Bioskop Dian sebagai wadah aktivitas dapat memenuhi kebutuhan ruang sesuai fungsi secara maksimal.

\section{c. Gagasan Fungsi Alternatif}

Setelah dilakukan analisis pada subbab sebelumnya, dalam menentukan sebuah fungsi baru perlu melihat regulasi daerah yang berlaku, kondisi kawasan dan bangunan, sejarah bangunan, serta mempelajari karakteristik ruang pada bangunan bioskop yang menjadi batasan bagi fungsi baru selanjutnya.

Dari hasil analisis kawasan yang sudah dilakukan, penulis melihat adanya kelompok kegiatan yang dominan dan berpotensi besar untuk diselengarakan pada kawasan tersebut sebagai wadah dari aktivitas yang dilakukan di sektar kawasan. Diantaranya ialah kelompok kegiatan Perdagangan dan Jasa, Olahraga/ Hiburan/ Rekreasi, dan Fasilitas Pendidikan.

Dari kelompok kegiatan tersebut, masing- masing akan dipilih satu fungsi yang paling sesuai yang didasari oleh pertimbangan adaptive reuse, yaitu building type function atau tipologi bangunan ${ }^{11}$ dan faktor lainnya seperti, nilai sejarah, nilai sosial-budaya, serta nilai yang terkandung pada kawasan.

Bangunan bioskop memiliki tipologi yang sama dengan bangunan teater, maka karakteristik ruang yang ada pada bangunan ini harus disesuaikan dengan kebutuhan ruang untuk fungsi baru yang bisa menyesuaikan dengan masa kini. Karena Bioskop Dian dikategorikan sebagai Bangunan Cagar Budaya Golongan A, maka diwajibkan untuk tidak merubah susunan ruang dalamnya.

\footnotetext{
${ }^{11}$ Murtagh, William J. (2006). Keeping Time: The History and Theory of Preservation in America. America: John Wiley \& Sons Inc.
} 
Tabel 1 Gagasan Fungsi Alternatif

\begin{tabular}{|c|c|c|c|c|}
\hline No & $\begin{array}{c}\text { Kelompok } \\
\text { Kegitan }\end{array}$ & $\begin{array}{c}\text { Fungsi } \\
\text { Alternatif }\end{array}$ & Ide & Alasan \\
\hline 1 & $\begin{array}{l}\text { Perdagang } \\
\text { an dan } \\
\text { Jasa }\end{array}$ & Toko & $\begin{array}{l}\text { Toko Oleh- } \\
\text { Oleh Khas } \\
\text { Kota } \\
\text { Bandung; } \\
\text { makanan, } \\
\text { pakaian, } \\
\text { serta } \\
\text { cinderamata. }\end{array}$ & $\begin{array}{l}\text { Melihat data fungsi eksisting } \\
\text { sekitar, fungsi toko sebagai } \\
\text { pusat oleh-oleh belum } \\
\text { ditemukan di kawasan tersebut, } \\
\text { sehingga adanya fungsi ini dapat } \\
\text { menjadi fungsi pertama yang } \\
\text { terdapat pada kawasan tersebut } \\
\text { untuk menarik para wisatawan. }\end{array}$ \\
\hline 2 & $\begin{array}{l}\text { Olah } \\
\text { Raga/ } \\
\text { Hiburan/ } \\
\text { Rekreasi }\end{array}$ & $\begin{array}{l}\text { Gelangga } \\
\text { ng } \\
\text { Remaja }\end{array}$ & $\begin{array}{l}\text { Gelangang } \\
\text { Remaja Tipe } \\
\text { A/ Pemula. }\end{array}$ & $\begin{array}{l}\text { Gelanggang Remaja yang } \\
\text { dimaksud merupakan sebuah } \\
\text { fasilitas untuk bersosialisasi dan } \\
\text { mengembangkan diri agar dapat } \\
\text { menghasilkan komunitas yang } \\
\text { berkelanjutan dan kompeten. } \\
\text { Melihat kawasan Alun-alun } \\
\text { yang merupakan kawasan } \\
\text { karyapolis, dirasa fungsi ini } \\
\text { cukup tepat untuk dapat } \\
\text { mengasah kemampuan generasi } \\
\text { muda dalam mengasah bakatnya } \\
\text { untuk berpikir kreatif dan } \\
\text { inovatif. }\end{array}$ \\
\hline 3 & $\begin{array}{l}\text { Fasilitas } \\
\text { Pendidika } \\
\mathrm{n}\end{array}$ & $\begin{array}{l}\text { Sanggar } \\
\text { Seni }\end{array}$ & $\begin{array}{l}\text { Sangar Seni } \\
\text { dan Galeri, } \\
\text { khususnya } \\
\text { dalam } \\
\text { bidang seni } \\
\text { pertunjukka } \\
\text { n;perfilman, } \\
\text { teater, dan } \\
\text { lainnya. }\end{array}$ & $\begin{array}{l}\text { Kawasan tapak termasuk dalam } \\
\text { SWK Karees, yang merupakan } \\
\text { kawasan karyapolis, yaitu } \\
\text { pengembangan Kawasan Kreatif } \\
\text { Terpadu. } \\
\text { Ide dalam sanggar seni dan } \\
\text { galeri dipilih sebagai wadah } \\
\text { untuk masyarakat dapat } \\
\text { berkegiatan seperti seni teater, } \\
\text { workshop perfilman, yang } \\
\text { hasilnya dapat dipertunjukkan. } \\
\text { Hal ini juga dapat menarik para } \\
\text { wisatawan untuk melihat } \\
\text { pameran ataupun pertunjukkan } \\
\text { yang sedang berlangsung. }\end{array}$ \\
\hline
\end{tabular}

Setiap fungsi tersebut mempunyai persyaratannya masing-masing. Persyaratan tersebut terbagi atas lokasi, kebutuhan ruang, target pengguna, dan lingkungan. Setelah itu dievaluasi menurut prinsip adaptive reuse yaitu, memory and place, planning control, environmental sustainability, social sustainabiliy, efficiency, dan authenticity. Sehingga menghasilkan evaluasi seperti tabel berikut ini: 
Tabel 2 Rangkuman hasil evaluasi terhadap prinsip adaptive reuse

\begin{tabular}{|c|c|c|c|c|}
\hline \multirow[t]{2}{*}{ No } & \multirow{2}{*}{$\begin{array}{c}\text { Prinsip Adaptive } \\
\text { Reuse }\end{array}$} & \multicolumn{3}{|c|}{ Fungsi } \\
\hline & & $\begin{array}{l}\text { Toko Oleh- } \\
\text { Oleh Khas } \\
\text { Bandung }\end{array}$ & $\begin{array}{l}\text { Gelanggang } \\
\text { Remaja }\end{array}$ & $\begin{array}{l}\text { Sanggar Seni } \\
\text { dan Galeri }\end{array}$ \\
\hline 1 & Memory and Place & - & - & $\sqrt{ }$ \\
\hline 2 & Planning Control & $\sqrt{ }$ & $\sqrt{ }$ & $\sqrt{ }$ \\
\hline 3 & $\begin{array}{l}\text { Environmental } \\
\text { Sustainability }\end{array}$ & $\sqrt{ }$ & $\sqrt{1}$ & $\sqrt{ }$ \\
\hline 4 & Social Sustainability & - & $\sqrt{1}$ & $\sqrt{ }$ \\
\hline 5 & Efficiency & - & - & $\sqrt{ }$ \\
\hline 6 & Authenticity & $\sqrt{ }$ & $\sqrt{ }$ & $\sqrt{ }$ \\
\hline
\end{tabular}

Dari hasil evaluasi tersebut, fungsi yang paling sesuai untuk diaplikasikan pada Bioskop Dian ialah fungsi Sanggar Seni dan Galeri karena fungsi tersebut memenuhi seluruh nilai prinsip adaptive reuse, sedangkan fungsi toko hanya memenuhi tiga dari enam nilai, dan fungsi gelanggang remaja mendapat empat dari enam nilai.

Hasil fungsi yang didapat untuk dapat diaplikasikan pada bangunan Bioskop Dian sebagai Bangunan Cagar Budaya Golongan A merupakan hasil analisis dan pandangan dalam bidang arsitektur. Dalam penerapannya, perlu adanya campur tangan dari para ahli sejarah, ahli ekonomi, ahli cagar budaya, ahli tata kota, dan lainnya yang dapat memberi pandangan masingmasing terkait fungsi terbaik untuk diterapkan pada bangunan ini.

\subsection{GAGASAN RENCANA FUNGSI SANGGAR SENI DAN GALERI}

a. Rencana ruang luar

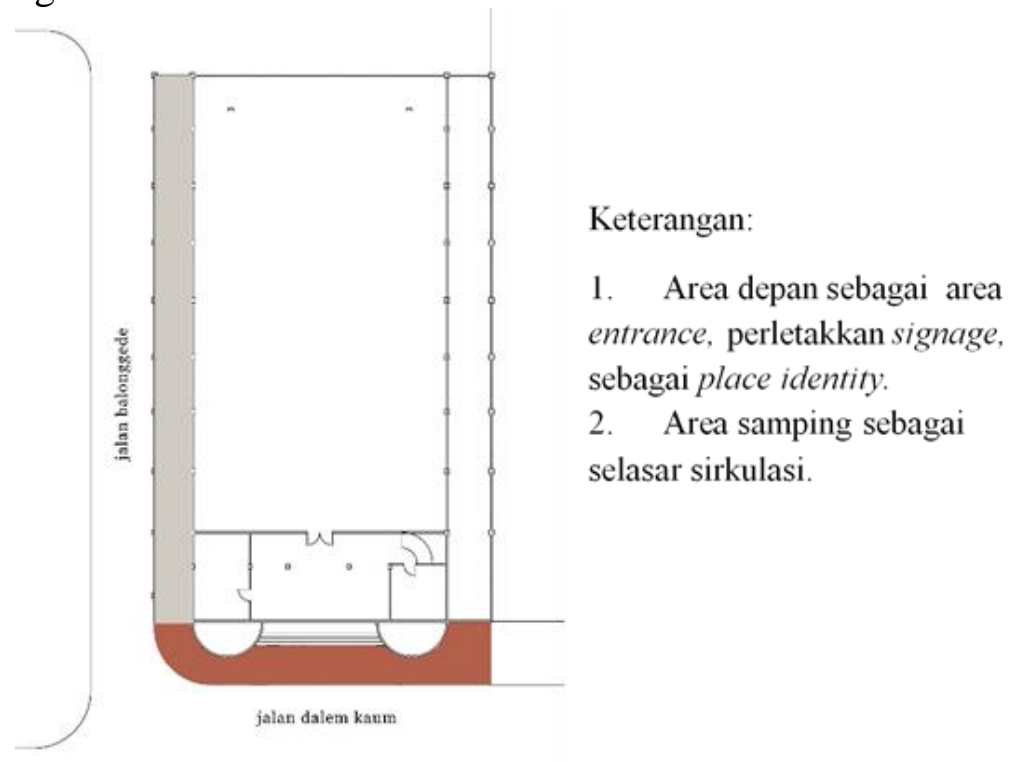

Gambar 8 Rencana ruang luar 
b. Rencana ruang dalam

1) Lantai Dasar

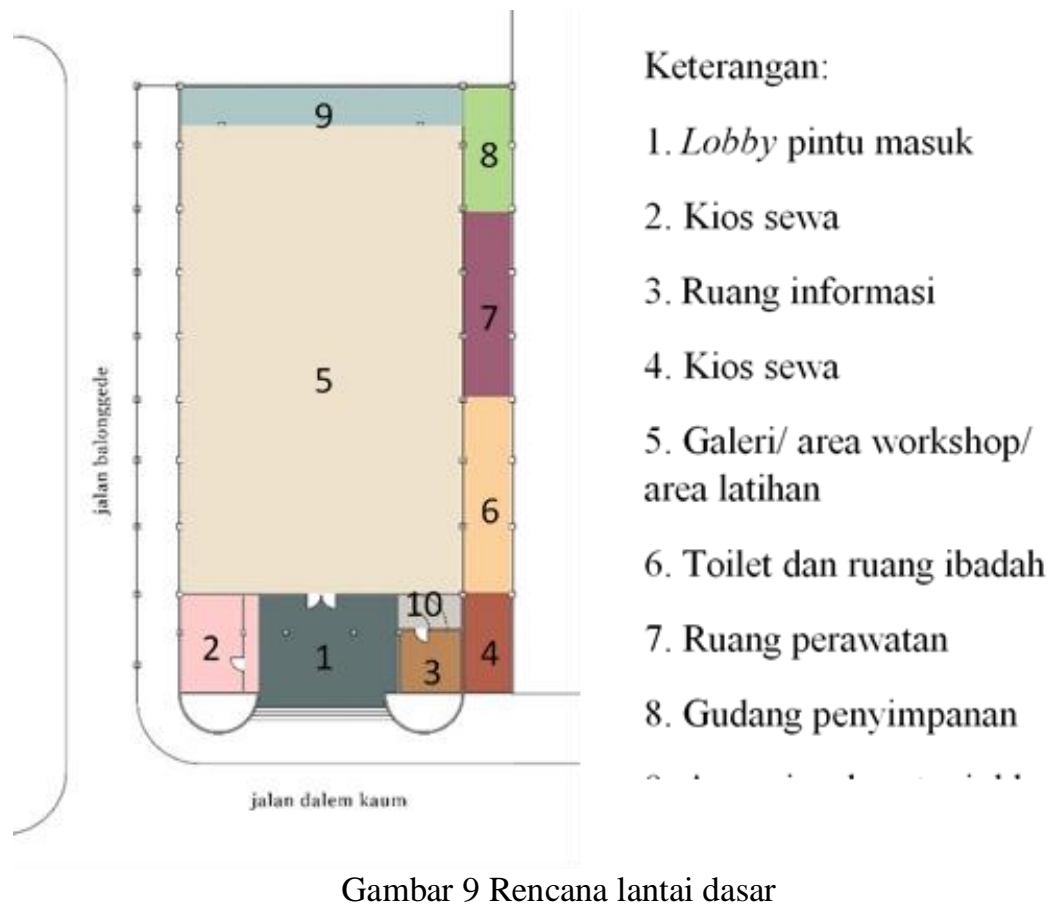

2) Lantai 1

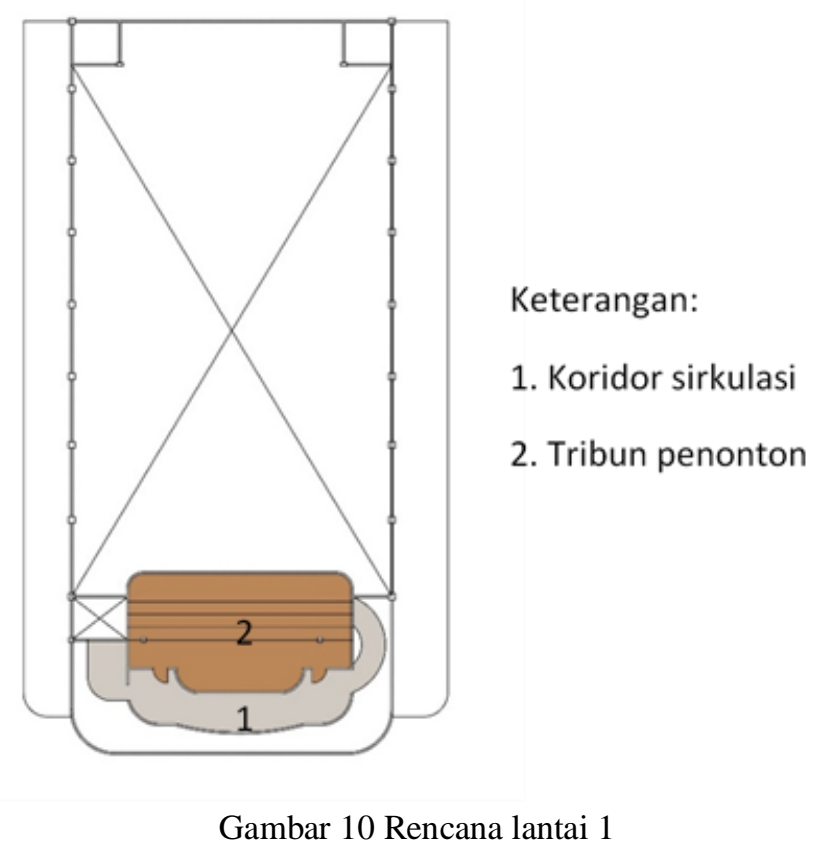

3) Lantai 2 


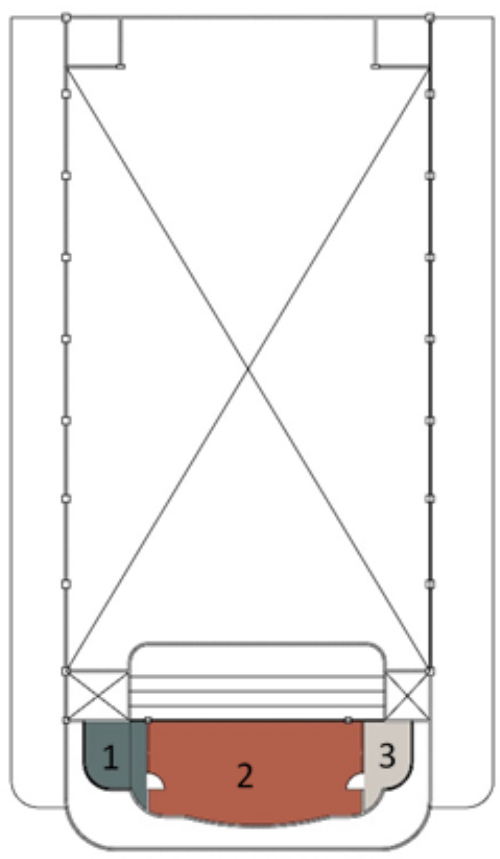

Keterangan:

1. Akses sirkulasi

2. Ruang pengelola

3. Ruang arsip

Gambar 11 Rencana lantai 2

\section{KESIMPULAN}

Setelah melakukan tahap pengumpulan data dan analisis, maka dapat diambil kesimpulan dari pertanyaan penelitian:

Apa fungsi baru yang sesuai untuk diaplikasikan pada Bioskop Dian sebagai Bangunan Cagar Budaya Golongan A di Kota Bandung?

Hasil analisis pada penelitian menunjukkan bahwa sanggar seni dan galeri khususnya dalam bidang seni pertunjukkan dinilai sesuai untuk diaplikasikan pada Bioskop Dian. Nilai prinsip adaptive reuse yang diuji memenuhi semua nilai prinsip tersebut. Adanya fungsi baru ini diharapkan dapat membangkitkan memori sejarah lama yang mulai pudar, meningkatkan wawasan masyarakat di bidang pendidikan melalui sebuah karya seni, menjadi salah satu destinasi wisata rekreasi maupun edukasi bersejarah yang berada di kawasan, turut serta untuk memelihara, melindungi, dan memafaatkan eksistensi Bangunan Cagar Budaya Golongan A di Kota Bandung. Diharapkan juga, adanya gagasan fungsi yang diusulkan melalui hasil penelitian dalam segi pandang bidang arsitektur ini dapat menjadi bahan pertimbangan untuk pengelola bangunan Bioskop Dian.

Sejarah merupakan hal yang penting. Maka dari itu, diperlukan etika dalam upaya untuk mengkonservasi sebuah bangunan cagar budaya. Diperlukan kesadaran dalam diri, untuk menyelamatkan sebuah nilai sejarah penting yang makin hari semakin pudar digerus zaman. Dengan adanya upaya adaptif, atau disebut sebagai adaptive reuse, bangunan akan dapat menyesuaikan kondisinya sesuai zaman agar tidak hilang eksistensinya, terutama pada bangunan cagar budaya. Langkah adaptive reuse merupakan cara ekonomis dalam menyelamatkan bangunan. 


\section{DAFTAR PUSTAKA}

\section{Buku}

Bunnel, Gene. (1978). Built to Last: A Handbook on Recycling Old Buildings. Massachusetts: Preservation Press.

Feilden, Bernard M. (1982). Conservation of Historic Building. Oxford: Butterworth Heinemann Ltd.

Orbasli, Aylin. (2008). Architectural Conservation. Britania Raya: Blackwell Publishing.

Office for Design and Architecture. (2014). Adaptive Re-Use Guidance. Australia: Government of South Australia.

\section{Peraturan}

Peraturan Daerah Kota Bandung No. 7 Tahun 2018 tentang Pengelolaan Cagar Budaya.

Peraturan Daerah Kota Bandung No. 10 Tahun 2015 tentang Rencana Detail Tata Ruang dan Peraturan Zonasi Kota Bandung tahun 2015- 2035.

Undang - Undang Republik Indonesia No. 11 Tahun 2010 tentang Cagar Budaya.

\section{Piagam}

ICOMOS. (1999). International Cultural Tourism Charter: Managing Tourism at Places of Heritage Significance.

ICOMOS. (1999). The Burra Charter: The Australia ICOMOS Charter for Places of Cultural Significance.

\section{Jurnal}

Hmood, K.F. (2019). Introductory Chapter: Heritage Conservation Rehabilitation of Architectural and Urban Heritage, Urban and Architectural Heritage Conservation within Sustainability. IntechOpen.

Misirlisoy, D., Günçe, K. Adaptive reuse strategies for heritage buildings: A holistic approach. Elsevier. Vol.26. 91-98.

\section{Skripsi}

Adhiguna, Z. (2011). Upaya Konservasi pada Bangunan Ex-Bioskop Dian. Disertasi tidak diterbitkan. Bandung: Universitas Katolik Parahyangan

Kusumaningrum, D.R. (2019). Usulan Kecocokan Fungsi dengan Upaya Adaptive Reuse pada Bangunan Cagar Budaya Puskesmas Tamblong, Bandung. Disertasi tidak diterbitkan. Bandung: Universitas Katolik Parahyangan 